\title{
The mechanisms of action of cyclosporin A in the treatment of psoriasis
}

\section{Robert L. Wong, Christine M. Winslow and Kevin D. Cooper}

\begin{abstract}
This article describes the effects of cyclosporin $A$ (CsA) on the immunopathological mechanisms operative in psoriasis, a human skin disease. The main focus is the effect of CsA on keratinocytes, $T$ cells and antigen-presenting cells, the key players in lesional psoriatic skin. The effect of CsA on other cells, such as neutrophils and endothelial cells, which are important in the maintenance of psoriasis, are also discussed.
\end{abstract}

Cyclosporin A (CsA, Sandimmune ${ }^{\circledR}$ ) is a neutral, lipophilic, cyclic undecapeptide that has been used extensively as an immunosuppressive agent in the prevention of allograft rejection ${ }^{1}$. Its effectiveness in psoriasis has been well established for the oral route of administration in many studies, especially in patients who had failed phototherapy or methotrexate ${ }^{2}$. No definitive animal model for psoriasis exists, so that the mechanism of action of CsA in the disease is incompletely understood.

The immunosuppressive action of CsA has not yet been fully elucidated, although significant advances have recently been made toward this goal ${ }^{3}$. CsA binds an intracellular receptor termed cyclophilin. The CsA-cyclophilin complex inhibits calcineurin, a calcium- and calmodulin-dependent phosphatase ${ }^{4}$. It is hypothesized that inhibition of the phosphatase activity of this enzyme prevents the translocation across the nuclear-membrane of the cytoplasmic subunit of the nuclear factor of activated T cells (NF-AT), a transcription factor essential for the transcription of the interleukin 2 (IL-2) gene ${ }^{3,5}$. Thus, despite upregulation of the IL-2 receptor, the lack of IL-2 production results in secondary impairment of IL-2-driven proliferation of activated $\mathrm{T}$ cells ${ }^{6}$.

IL-2 production is inhibited by CsA and this prevents the secondary production of other T-cell cytokines, including macrophage migration inhibition factor (MIF), macrophage procoagulant activity, gammainterferon (IFN- $\gamma$ ) and granulocyte-macrophage colony stimulating factor $(\mathrm{GM}-\mathrm{CSF})^{7-9}$. In this way, IL-2-dependent immune amplification may be suppressed sufficiently to keep cellular immune reactivity below a critical threshold. CsA is not myelosuppressive at immunosuppressive doses and, since it is not lymphocytotoxic, its immunosuppressive effects are reversible following discontinuation of therapy?

Human epidermis maintains the peak serum concentra tion of CsA after oral administration ${ }^{10}$. Skin biopsies obtained from psoriatic patients treated for seven days with a very high dose of CsA (14 mg kg-1 day-1) had intracellular CsA concentrations (based on tissue wet weight) of $2.8 \mu \mathrm{M}$, roughly 10 times that of trough blood samples. In patients treated with lower doses of
CsA, intracellular epidermal CsA concentrations were

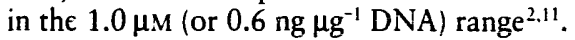

\section{The psoriatic plaque}

The epidermis and dermis of an active psoriatic plaque contain increased numbers of several different cells of the immune system, including lymphokinesecreting activated $T$ cells, activated antigen-presenting celis (APCs) (Langerhans cells, macrophages and dendritic cells), polymorphonuclear leukocytes and hyperproliferating keratinocytes $(\mathrm{KCs})^{11-16}$.

Although the initiating events that lead to psoriasis are unknown, a model can be proposed for interactions of the immune system with cutaneous elements that result in several self-perpetuating mechanisms within a psoriatic plaque (Fig. 1). Initiation of the psoriatic lesion may be due to either microbial or physical damage to the skin, or to systemic or local antigenic, autoantigenic, or superantigenic substances. The activation of APCs, KCs, or dermal cells can result in induction of antigen presentation, cytokine release and enhanced T-cell activation. The enhanced level of antigen presentation by APCs (in particular macrophages, but possibly also dendritic cells and Langerhans cells) within the epidermis or dermis results in helper T-cell $\left(T_{H}\right)$ activation and lymphokine release. Certain lymphokines, including GM-CSF, IL-3, insulin-like growth factor-1 and IL-2, may have direct effects on KCs, resulting in hyperproliferation and accelerated differentiation ${ }^{17,18}$; the altered phenotype of lesional $\mathrm{KCs}$ (increased expression of intercellular adhesion molecule-1 (ICAM-1), HLA-DR and secretion of IP-10) is indicative of in vivo exposure to lymphokines such as IFN- $\gamma$. In addition, IFN- $\gamma$ itself and lesional $\mathrm{T}$ cells which produce IFN- $\gamma$, directly upregulate the expression of ICAM-1 ${ }^{13,19}$. Other lymphokines can cause mast cell degranulation and tumor necrosis factor (TNF) release. Cytokines such as IL-1 and TNF, which are released from injured epidermis, could also induce the expression of ICAM-1 and E-selectin on the microvascular endothelium, thereby enhancing the adhesiveness of endothelium for circulating leukocytes. Simultaneously, the activation of $T$ cells in lymph nodes, gut or other skin sites and the maturation of 


\section{review}

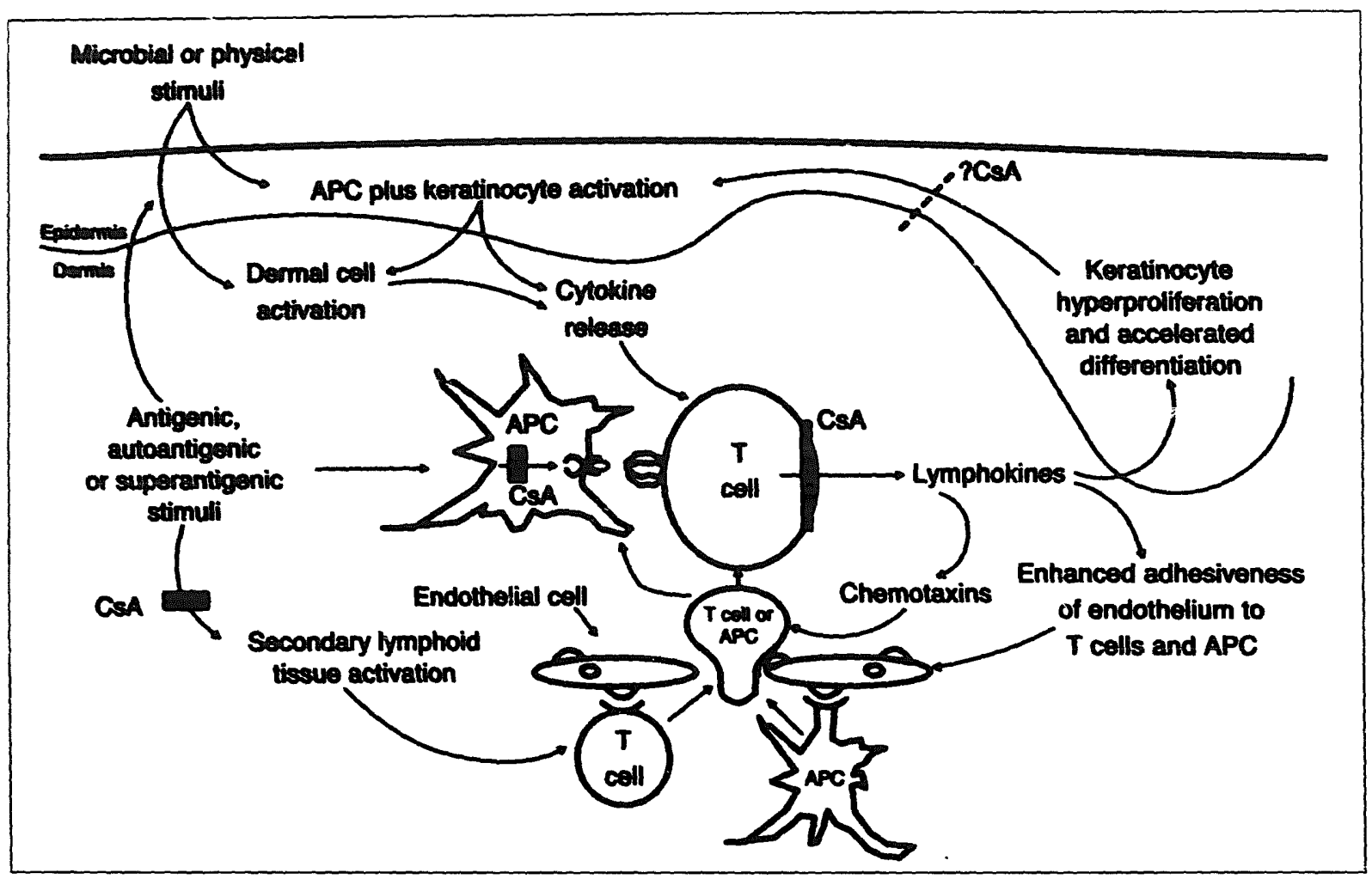

Fig. 1. Model of the self-perpetuating immunological mechanisms in psoriatic lesional skin. Sites of action of cyclosporin A (CsA) are noted.

naive $T$ cells to memory $T$ cells (plus their subsequent activation) results in upregulation of leukocyte integrins and selectin ligands that enhance $T$-cell adhesiveness to endothelial selectins and immunoglobulin superfamily adhesion molecules. Together, these events increase the adhesion of circulating leukocytes to endothelial cells, and are followed by leukocyte diapedesis and localization to the skin. Increased leukocyte density enhances the likelihood of T-cell-APC interactions and further stimulation of $T$ cells, macrophages, dendritic cells, KCs, mast cells and endothelial cells ${ }^{20}$.

All of these cells are potential sources of cytokines. IL-1 regulation is disordered in psoriatic skin ${ }^{21}$ and the overall balance of cytokines released by lesional psoriatic epidermis potentiates $\mathrm{T}$-cell activation, whereas the norma' skin cytokine balance has no net positive or negative effect on T-cell activation ${ }^{22}$. Thus, epidermal cytokine release can further propagate $T$-cell activation in psoriatic lesions. Furthermore, IL-1, IL-6 and IL-8 can induce epidermal hyperproliferation, either directly or through the induction of eicosanoid release by KCs. Cytokine-induced eicosanoid production, from macrophages and $\mathrm{KCs}$, or IL-8 production, from KCs, $T$ cells, and activated endothelium, induce chemoattractants (chemotaxins) for T-cell and APC diapedesis and epidermotropism. These chemotaxins also attract polymorphonuclear leukocytes, which can accumulate to produce micro-abscesses and, in severe cases of psoriasis, pustulation ${ }^{23}$.
As CsA can inhibit, directly or indirectly, one or more key steps in this immunological cascade, a rational basis for CsA in the treatment of psoriasis can be postulated (Fig. 1). A critical bottleneck for maintenance of these self-propagating mechanisms is the APC induction of T-cell lymphokine release. The welldemonstrated activity of CsA to block T-cell lymphokine release at levels easily achieved within psoriatic lesions clearly implicates this mechanism at work. Whether CsA treatment also works via APC inhibition depends on whether or not the lesion is primarily maintained by signals from macrophages, which are resistant to CsA concentrations achieved in vivo, or by Langerhans cells, which are sensitive to levels of CsA achieved during in vivo psoriasis therapy ${ }^{11.24}$. A direct action on $\mathrm{KC}$ activation has also been postulated for $\mathrm{CsA}$; however, this is controversial as relatively high intracellular CsA concentrations are required to modulate $\mathrm{KCs}^{10}$

\section{The effects of CsA on keratinocytes \\ Keratinocyte proliferation}

Kato et al. ${ }^{25}$ have suggested that CsA at a concentration 30 times $(6 \mu \mathrm{M})$ the expected trough serim level does not inhibit epidermal cell growth; these conclusions were based on in vitro studies of a pig skin explant culture system ${ }^{25}$. The occurrence of gingival epithelial hyperplasia as a side effect of human in vivo CsA therapy ${ }^{2}$ and the lack of an effect by CsA on lamellar ichthyosis (a hyperproliferative skin disease) ${ }^{26}$ 


\section{review}

also argue against a potent antiproliferative effect of CsA on epithelia. Maintenance of the hyperproliferative keratin phenotype and overexpression of EGF-Rs and transforming growth factor $\alpha$ (TGF- $\alpha$ ) by KCs in the face of CsA therapy also supports the concept that $\mathrm{CsA}$ does not have a potent antiproliferative effect on $\mathrm{KCs}^{27.28}$

The interpretation of in vitro studies is heavily influenced by the culture conditions ${ }^{10}$. Lack of serum in the media may result in CsA (which is hydrophobic) leaving the media and entering cells, such that an original media concentration of $1 \mu \mathrm{M}$ can result in intracellular CsA concentrations of $9.4 \mathrm{ng}^{\mathrm{g}} \mathrm{g}^{-1}$ DNA under serum free conditions and $5 \mathrm{ng} \mathrm{\mu g}^{-1}$ DNA under serum containing conditions ${ }^{10.11}$. These values are eight- and fivefold greater, respectively, than the intracellular concentrations actually achieved in vivo with a very high oral dose of $14 \mathrm{mg} \mathrm{kg}{ }^{-1}$ day and fifteen- and eightfold

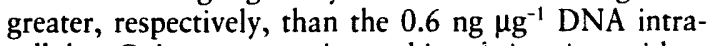
cellular CsA concentration achieved in vivo with a lower, but still clinically effective, dose of $3 \mathrm{mg} \mathrm{kg}^{-1} \mathrm{~d}^{-1}$ (Refs 2,11).

Several studies have demonstrated inhibition of in vitro $\mathrm{KC}$ proliferation by $\mathrm{CsA}$ in a dose-dependent fashion ${ }^{29,32}$. However, this occurs only under serumfree conditions, at the high concentrations of CsA of 1-10 $\mu \mathrm{M}^{10.30-32}$. Furue et al..$^{29}$ demonstrated dosedependent $(0.3-10 \mu \mathrm{M})$ and time-dependent (48-72 hour) inhibition of both DNA synthesis and cell proliferation in normal and transformed mouse and human epidermal cells ${ }^{29}$. Nickoloff et al. ${ }^{31}$ suggested that CsA could directly injure normal human $\mathrm{KCs}$; this was assessed using a chromium release assay and KCs that were exposed to high concentrations of $\mathrm{Cs} \AA$ (10 and $20 \mu \mathrm{M}$ ) for 5 to 72 hours under serum-free conditions ${ }^{30}$.

The significance of these findings is unclear because the intracellular CsA concentration required to inhibit the proliferation of KCs in vitro may not be achievable in psoriatic patients ${ }^{10}$. One possible explanation for the lack of correlation between in vino and in vitro experiments is that, although CsA may reduce the number of DNA-synthesizing cells ${ }^{33.34}$, an enhanced $\mathrm{KC}$ lifespan in vivo may occur after CSA therapy ${ }^{33}$.

\section{Cytokine production}

Keratinocyte cytokines that may be important for the trafficking of peripheral blood monocytes and lymphocytes toward the epidermis include, among others, lymphocyte chemotactic factor, IL-1, IL-8, leukotriene $\mathrm{B}_{4}$ and TGF- $\beta$ (Refs 35-41). Stimulation by T-cell lymphokines, for example IFN- $\gamma$, is a likely mechanism of induction of $\mathrm{KC}$ secretion of other proinflammatory cytokines, such as IP-10, GM-CSF, TNF- $\alpha$, IL-1, IL-6 and IL-8 ${ }^{42-49}$. IP-10, a chemokine with possible chemotactic and mitogenic activity, has been detected in hurnan KCs in psoriatic plaques ${ }^{42}$. A structurally related chemokine, IL-8 (which may be synthesized locally), is a neutrophil and T-cell chemoattractant; it has also been detected in psoriatic plaques ${ }^{47}$. IL-1 is significantly abnormal in psoriatic skin; elevated levels of a dysfunctional IL-1 $\beta$, low levels of IL-1 $\alpha$, and an elevated ratio of IL-1 receptor antagonist (IL-1ra) to IL-1 are found ${ }^{50}$.
In summary, although CsA may have some direct effects on epider 'nal cytokines that modulate immune function ${ }^{51}$, such effects have been difficult to demonstrate in keratinocytes. However, CsA may have an indirect effect on $\mathrm{KC}$ cytokine production by inhibiting $T$-cell activation and secondary $K C$ activation. In support of this, IP-10, IL-1 $\beta$ and IL- 8 are reduced in lesions during CsA therapy ${ }^{52.53}$, although CsA had no direct effect on IL-1 or IL-8 induction by KCs cultured ex vivo or in vitro.

\section{Cell surface molecule expression}

$\mathrm{kCs}$ from uninvolved (nonlesional) skin of psoriatic patients express neither HLA-DR nor ICAM-1 molecules $^{12.54}$; in contrast, epidermal KCs from psoriatic plaques express a number of cell surface molecules, including ICAM-1 and HLA-DR ${ }^{12,16,54,55}$, which may be important in mediating an inflammatory process. ICAM-1 expression by $\mathrm{KCs}$ in psoriatic plaques is reduced after intralesional CsA therapy ${ }^{56}$ and HLA-DR expression by psoriatic KCs rapidly decreases after oral CsA administration, preceding the physical loss of $T$ cells and macrophages from lesional skin ${ }^{i 3.24}$. These data suggest that continuous $\mathrm{T}$-cell lymphokine production is necessary for ICAM-1 and HLA-DR expression, and it is possible that the expression of these molecules by $\mathrm{KCs}$ in lesions can be taken as an in vivo human bioassay of lesional $\mathrm{KC}$ exposure to lymphokines.

\section{The effects of CsA on T cells \\ $T$-cell infiltration}

By blocking the transcription of the IL-2 gene, CsA impairs IL-2-driven proliferation of activated $T_{H}$ and cytotoxic $\mathrm{T}$ lymphocytes (CTLs) ${ }^{1.3}$. IL-2-independent T-cell activation, however, appears resistant to $\mathrm{CsA}^{5-}$. Baker et al. ${ }^{13}$ demonstrated a decline in the number of epidermal CD4* (preferentially) and CD8 ${ }^{+} \mathrm{T}$ cells in six patients with severe psoriasis given $\mathrm{CsA}$ at an initial daily dose of $2 \mathrm{mg} \mathrm{kg}^{-1}$ (Ref. 13). This T-cell depletion correlated closely with a reduction in the extent and severity of disease and generally preceded clinical improvement. Depletion of both activated $\left(\mathrm{CD}^{+} \mathrm{DR}^{+}\right)$ and nonactivated (CD5 $\left.{ }^{+} R^{-}\right) \mathrm{T}$ cells from the epidermis and dermis of psoriatic patients within one week of treatment with CsA (14 mg kg${ }^{-1}$ day $\left.^{-1}\right)$ has been reported ${ }^{14}$. Clearance appeared to occur concomitantly with (and perhaps before) clinical resolution ${ }^{14}$. Rapid reduction of activated T cells bearing IL-2 and transferrin receptors in lesional skin following CsA therapy has been noted by several authors ${ }^{2-.58}$.

\section{Lymphokine secretion}

T-cell-derived lymphokines appear to play an important role in the pathophysiology of the psoriatic plaque. IFN- $\gamma$ is associated with the mononuclear cells in the dermal cell infiltrate, stratum corneum, and KCs of psoriatic lesions ${ }^{59}$, and the administration of IFN- $\gamma$ or IL-2 can worsen psoriatic lesions ${ }^{60,61}$. Skin-infiltrating T-cell clones that produce IFN- $\gamma$ and IL-2 have been identified in psoriatic lesions ${ }^{19}$. Since CsA can inhibit the release of T-cell-derived lymphokines, this is one possible mechanism by which CsA can indirectly 


\section{review}

modify other cells that contribute to the inflammatory process and propagation of the psoriatic skin lesion ${ }^{7-9}$.

Although no alterations in circulating $\mathrm{T}$-cell phenotype or function (following phytohemagglutinin, concanavalin $A$ and purified protein derivative (PPD) stimulation) have been noted in psoriasis patients during CSA therapy ${ }^{58.62}$, a mild degree of immunosuppression during psoriasis is detectable. The concentration of secreted IL-2Rs in the serum is reduced ${ }^{63}$, and there is a significant reduction in the elicitation of delayedtype hypersensitivity reactions in uninvolved skin during CsA therapy ${ }^{2}$.

\section{The effects of CsA on antigen-presenting cells Antigen presentation}

Many cell types that are potentially capable of antigen presentation are found in the epidermis and dermis of patients with psoriasis. They include the CDla ${ }^{+} \mathrm{HLA}^{-\mathrm{DR}^{+}}$Langerhans cells, monocytes/ macrophages, dendritic cells and KCs (Ref. 16).

The role of the Langerhans cell within the lesional skin is unclear. Although maturation of Langerhans cells into potent dendritic APCs has been proposed to account for elevated APC activity in lesions ${ }^{64}$, depletion of $\mathrm{CD} \mathrm{a}^{+}$Langerhans cells from lesional psoriatic epidermis did not significantly reduce presentation of either alloantigen ${ }^{16}$ or autoantigen ${ }^{65}$, indicating that psoriatic lesional Langerhans cells may even be downmodulated. Both the increased alloantigen- and autoantigen-presenting capacity appear to be due to infiltrating CD1a-DR ${ }^{+} \mathrm{APCs}^{16,65}$. Furthermore, proliferating $\mathrm{CD}^{\circ} 5^{+} \mathrm{RO}^{+}$lymphoblastoid cells in the lesional dermis are seen in apposition to cells expressing a macrophage phenotype ${ }^{66}$.

CsA appears to have inhibitory properties on various APCs in normal and lesional epidermis. Furue and $\mathrm{Katz}^{67}$ demonstrated that CsA $\left(0.1-10 \mu \mathrm{g} \mathrm{m}^{-1}\right)$ can inhibit the accessory cell function of murine epidermal Langerhans cells in vitro. Similarly, inhibition of antigen presentation by Langerhans cells cultured in vitro with CsA $\left(0.1 \mu \mathrm{g} \mathrm{ml}^{-1}\right.$ and $10 \mu \mathrm{g} \mathrm{ml}^{-1}$ serum-free, respectively) in a mixed epidermal cell-lymphocyte reaction was shown ${ }^{64,68}$. Although autoantigen presentation by lesional psoriatic epidermal cells could be inhibited by exposure to high CsA concentrations $\left(10 \mu \mathrm{g} \mathrm{ml}^{-1}\right.$ in vitro), lesional APCs were inhibited to a lesser extent than cultured Langerhans cells from normal epidermis (twofold versus 4.5 -fold) ${ }^{64}$.

In studies of patients treated with $\mathrm{Cs} \mathrm{N}$, therapy did not result in any significant difference in the number of Langerhans cells between lesional and nonlesional epidermis $^{24}$. However, the aniigen-presenting activity of Langerhans cells from skin that appeared to be normal was rapidly inhibited by CsA. Interestingly, antigenpresenting activity of lesional skin previously shown to be due to $\mathrm{CD}^{-} \mathrm{a}^{-} \mathrm{DR}^{+}$cells ${ }^{16}$ that also express macrophage markers ${ }^{14}$ did not decrease until the CD1 $\mathrm{a}^{-} \mathrm{DR}^{+}$cells began to clear from the lesion, indicating that their intrinsic antigen-presenting activity was relatively CsA resistant ${ }^{24}$. The number and activity of the CD1a-DR+ macrophagic APCs correlated with the degree of lesional clearing $(r=0.84)$, suggesting an intimate association between these cells and propa- gation of the lesion. Their eventual disappearance with lesional clearing suggests that their recruitment was dependent on continued T-cell activation. Studies by Baker et al. ${ }^{13}$, involving psoriatic patients treated with CsA (2-3 $\mathrm{mg} \mathrm{kg}^{-1}$ day ${ }^{-1}$ initial dose) for at least six weeks, demonstrated a decrease in the number of $\mathrm{HLA}-\mathrm{DR}+\mathrm{CD} 1 \mathrm{a}^{-}$dendritic cells before clinical improvement at a rate that correlated with the clearance of psoriasis ${ }^{13}$, confirming the impression that APCs and $T$ cells interact in lesional skin in a selfsustaining cycle of positive feedback.

\section{Cytokine secretion}

There is a paucity of studies of the effects of CsA on cytokine secretion by APCs from psoriatic skin. In situ hybridization studies have revealed TNF- $\alpha$ in macrophages/dendrocytes from the papillary dermis of psoriatic patients; TNF- $\alpha$ induces KC secretion of IL-8 and TGF- $\alpha$, as well as ICAM-1 expression ${ }^{47}$. A pathophysiological model of psoriasis might predict that IL-1 (secreted by KC and macrophages) would play a significant role in the pathogenesis of psoriasis ${ }^{22}$, and IL-1 has been visualized in perivascular leukocytes in the dermis of lesional psoriasis ${ }^{21}$. Although CsA mav indirectly reduce $\mathrm{T}$-cell activation by inhibiting the release of non-T-cell cytokines that potentiate $\mathrm{T}$-cell activation, it is not clear whether modulation of cytokines by CsA therapy occurs through reduction of macrophage or KC-cytokine production ${ }^{22}$.

\section{Other eiffects of Csit}

Neutrophil chemoattractants, such as platelet activating factor (PAF) and leukotriene $\mathrm{B}_{4}\left(\mathrm{LTB}_{4}\right)$ are increased in psoriatic tissue ${ }^{69}$. Since IL-1 and IL-8 from KCs may regulate the production of these chemoattractants, CsA-mediated inhibition of $\mathrm{KC}$ secretion may affect polymorphonuclear recruitment. CsA inhibits the chemotactic activity of PMNs from the peripheral blood of psoriatic patients treated with a single daily oral dose of CsA (3 mg kg-1 day $\left.{ }^{-1}\right)$ for three weeks ${ }^{70}$. Chemotactic activity was assayed using a two section chamber with the chemotactic factor $\mathrm{N}$-formyl-methionyl-leucyl-phenylalanine (FMLP). There was a significant decline in neutrophil migration at the first, second, and fourth weeks, relative to baseline values. CsA (50 $\left.\mathrm{ng} \mathrm{m}^{-1}\right)$ inhibited TNF and GM-CSF production by peripheral blood monocytes from psoriatic patients, and these two cytokines appeared to be responsible for the chemotactic activity for $\mathrm{PMN}^{70}$

The respiratory burst of PMN stimulated with FMLP or C5a is inhibited by CsA at concentrations as low as $0.05 \mu \mathrm{M}$ when measurcd in a chemiluminescence sisay (A. Stutz, unpublished resuits).

Dermal papillary vascular endothelium may, in psoriasis, be induced to express elevated levels of adhesion molecules, such as ICAM-1 or E-selectin, the ligancis of which are $\beta_{2}$ integrins or carbohydrate moieties on PMN and, possibly, on monocytes and skin-homing $T$ cells $s^{71}$. Since memory $T_{H}$ cells preferentially adhere to vesseis in psoriatic, but not in normal skin, the dermal endothelium appears to play an active role in lymphocyte recruitment ${ }^{72}$. No studies to date appear to have 


\section{review}

been done to evaluate the effect of CsA on E-selectin expression, but CsA has been shown to suppress ICAM-1 expression by papillary endothelium in psoriatic plaques ${ }^{3 / 3}$.

Mast cell numbers are increased early in the development of psoriatic lesions ${ }^{15}$, although their role in the disease is unclear. CsA $\left(0.1-0.2 \mu \mathrm{g} \mathrm{ml}^{-1}\right)$ significantly inhibits mast cell and basophil degranulation ${ }^{7,75}$, and the resulting reduced vasodilation and inflammation may be another anti-inflammatory mechanism of CsA action in psoriasis.

\section{Summary}

CsA inhibits T-cell production of IL- 2 and, consequently, the IL-2 driven proliferation of activated T cells and the secretion of other T-celi cytokines important in the immunolugical functions of $\mathrm{KCs}$, nonkeratinocyte antigen-presenting cells, and polymorphonuclear leukocytes in psoriatic skin. In addition, CsA has immunomodulatory effects on KCs and APCs, key members of the immunological network in the psoriatic plaque. These cumulative effects may result in disruption of the self propagating mechanisms of inflammation in psoriasis.

Robert L. Wong and Christine M. Winslow are at the Dept of Clinical Kesearch, Sandoz Research Institute, East Hanover, New Jersey 07936, USA, and Kevin D. Cooper is at the Immunodermatology Unit, Dept of Dermatology, University of Michigan Medical Center, Ann Arbor, Michigan 48109, USA.

\section{References}

1 Kahan, B.D. (1989) New Engl. J. Med. 321 (No. 25),

1725-1738

2 Ellis, C.N., Fradin, M.S., Messana, J.M. et al. (1991) New Engl. J. Med. 324, 277-284

3 Schreiber, S.L. and Crabtree, G.R. (1992) Immunol.

Today 13, 136-142

4 Liu, J., Farmer, Jr. J.D., Lane, W.S. et al. (1991) Cell 66, 807-815

5 Flanagan, W.M., Corthésy, B., Bram, R.J. and

Crabtree, G.R. (1991) Nature 352, 803-807

6 Buurman, W.A., Ruers, T.J.M., Daemen, I.A.J.J.M., Van

Der Linden, C.J. and Groenewegen, G. (1986) J. Immunol. $136,4035-4039$

7 Hess, A.D., Tutschka, P.J. and Santos, G.W. (1982) in Cyclosporine A: Proceedings of an International Conference on Cyclosporine A, pp. 209-231, Elsevier Biomedical Press 8 Kalman, V.K. and Klimpel, G.R. (1983) Cell. Immunol. 78, 122-129

9 Granelli-Piperno, A. (1990) J. Exp. Med. 171, 533-544

10 Fisher, G.J., Duell, E.A., Nickoloff, B.J. et al. (1988)

J. Invest. Dermatol. 91, 142-146

11 Cooper, K.D., Baadsgaard, O., Duell, E. et al. (1992)

J. Invest. Dermatol. 98, 259-260

12 Singer, K.H., Tuck, D.T., Sampson, Ii.A. and Hall, R.P. (1989) I. Invesi. Dermatol. 92, 745-750

13 Baker, B.S., Griftins C. E M. I. Aryber, E. et al. (1987)

Br. J. Dermatol. 116 (No. 4), 503-510

14 Gupta, A.K., Baadsgaard, O., Ellis, C.N., Voorhees, J.J. and Cooper, K.D. (1989) Arch. Dermatol. Res. 281, 219-226 15 Schubert, C. and Christophers, E. (1985) Arch. Dermatol. 277, 352-358

16 Baadsgaard, O., Gupta, A.K., Taylor, S. et al. (1989) J. Invest. Dermatol. 92, 190-195
17 Tavakkol, A., Elder, J.T., Griffiths, C.E.M. et al. (1992) J. Invest. Dermatol. 99, 343-349

18 Hancock, G.E., Kaplan, G. and Cohn, Z.A. 11988 J. Exp. Med. 168, 1395-1402

19 Baadsgaard, O., Tong, P., Elder, J.T. et al. (1990) J. Irvest. Dermatol. 95, 275-282

20 Picker, L.J., Kishimoto, T.K., Smith, C.W., Warnock, R.A. and Butcher, E.C. (1991) Nature 349, 796-799 21 Cooper, K.D., Hammerberg, C., Baadsgaard, O. et al. (1990) J. Immunol. 144, 4593-4603

22 Chang, E.Y., Hammerberg, C., Ellis, C.N. et al. (1992) Arch. Dermatol. 128, 1479-1485

23 Christophers, E. and Drueger, G.G. (1987) in

Dermatology in General Medicine. 3rd ed. (Fitzpatrick, T.B. Eisen, A.Z., Wolff, K., Freedberg, I.M., Austen, K.F., eds), pp. 461-491, McGraw-Hill

24 Cooper, K.D., Baadsgaard, O., Ellis, C.N., Duell, E. and Voorhees, J.J. (1990) J. Invest. Dermatol. 94, 649-656

25 Kato, N., Halprin, K.M. and Taylor, J.R. (1987)

J. Invest. Dermatol. 88, 52-54

26 Ho, V.C., Gupta, A.K. and Ellis, C.N. (1989) Arch. Dermaiol. 125, 511-514

27 Gottlieb, A.B., Grossman, R.M., Khandke, L. et al. (1992) J. Invest. Dermatol. 98, 302-309

28 Horrocks, C., Ormerod, A.D., Duncan, J.I. and Thomson, A.W. (1989) Clin. Exp. Immunol. 78, 166-171

29 Furue, M., Gaspari, A.A. and Katz, S.I. (1988) J. Invest. Dermatol. 90, 796-800

30 Nickoloff, B.J., Fisher, G.J., Mitra, R.S. and Voorhees, J.J. (1988) Transpl. Proc. 20, 85-90

31 Nickoloff, B.J., Fisher, G.J., Mitra, R.S. and Voorhees,

J.J. (1988) Am. J. Pathol. 131, 12-18

32 Sharpe, G.R. and Fisher, C. (1990) Br. J. Dermatol. 123, 207-213

33 Niimi, A., Tohnai, I., Kaneda, T., Takeuchi, M. and Nagura, H. (1990) J. Oral Pathol. and Med. 19, 397-403

34 Urabe, A., Kanitakis, J., Viac, J. and Thivolet, J. (1989) J. Invest. Dermatol. 92, 755-757

35 Ternowitz, T. and Thestrup-Pedersen, K. (1986)

J. Invest. Dermatol. 87, 613-616

36 Sauder, D.N., Monick, M.M. and Hunninghake, G.W. (1987) J. Invest. Dermatol. 85, 431-433

37 Payan, D.G. and Goetzl, E.J. (1981) J. Clin. Immunol. 1, 266-270

38 Wahl, S.M., Hunt, D.A., Wakefield, L.M. et al. (1987) Proc. Natl Acad. Sci. USA 84, 5788-5792

39 Luger, T.A., Stadler, B.M., Katz, S.I. and Oppenheim, J.J. (1981) J. Immunol. 127, 1493-1498

40 Sticherling, M., Bornscheuer, E., Schröder, J. and Christophers, E. (1991) J. Invest. Dermaiol. 96, 26-30 41 Ansel, J., Perry, P., Brown, J. et al. (1990) J. Intest Dermatol. 94, 101S-107S

42 Gottlieb, A.B., Luster, A.D., Posnett, D.N. and Carter, D.M. (1988) J. Exp. Med. 168, 941-948

43 Heufler, C., Koch, F. and Schuler, G. (1988) J. Exp. Med. 167, 700-705

44 Kupper, T.S., Ballard, D.W., Chua, A.O. et al. (1986) J. Exp. Med. 164, 2095-2100

45 Kupper, T.S., May, L., Birchall, M. and Sehgal, P. (1988)

J. Invest. Dermatol. 90,578

46 Sauder, D.N., Wong, D., McKenzie, R. et al. (1988)

J. Invest. Dermatol. 90, 605

47 Barker, J.N.W.N., Sarma, V., Mitra, R.S., Dixit, V.M. and Nickoloff, B.J. (1990) J. Clin. Invest. 85, 605-608 48 Nickoloff, B.J., Karabin, G.D., Barker, J.N.W.N. et al. (1991) Am. J. Pathol. 138, 129-140

49 Wasik, M.A. and Beller, D.I. (1989) Clin. Immunol. Immunopathol. 52, 331-340

50 Hammerberg, C., Arend, W.P., Fisher, G.J. et al. (1992) 


\title{
review
}

1. Clm. Inest. $90,571-583$

51 Belsito, D.V., Epstein, S.P., Schultz, J.M., Baer, R.L. and Thorbecke, G.J. (1989) J. Immunol. 143, 1530-1536

52 Gortliet, A.B., Krueger, J.G., Khandke, L. et al. (1991)

J. Invest. Dermatol. 96,570

53 Elder, J.T., Hammerberg, C., Barker, J. et al. (1991)

J. Imest. Dermatol. 96, 612A

54 Griffiths, C.E.M., Voorhees, J.J. and Nickoloff, B.J.

(1989) J. Am. Acad. Dermatol. 20,617-629

55 Gottlieb, A.B., Lifshitz, B., Fu, S.M. et al. (1986) J. Exp.

Med. 164, 1013-1028

56 Ho, V.C., Griffiths, C.E.M., Ellis, C..N. et al. (1990)

1. Am. Acad. Dermatol. 22, 94-100

57 Pereira, G.M.B., Miller, J.F. and Shevach, E.M. (1990)

J. Immunol. 144, 2109-2116

58 Horiocks, C., Duncan, J.l., Sewell, H.F., Ormerod, A.D. and Thomson, A.W. (1990) J. Autoimmunity 3, 559-570

59 Livden, J.K., Nilsen, R., Bjerke, J.R. and Matre, R.

1989, 'rch. Dermatol. Res. 281, 39:-397

60 Lee, R.E., Gaspari, A.A., Lotze, M.T., Chang, A.E. and

Rosenberg, S.A. (1988) Arch. Dermatol. 124, 1811-1815

61 Fierlbeck, G., Rassner, G. and Müller, C. 1990 i A $r c b$.

Dermatol. 126, 35i-355

62 Takashima, A. and Morita, A. (1991) J. Invest.

Dermatol. 96, 376-382

63 Duncan, J.I., Horrocks, C., Ormerod, A.D. et al. (1991)

Clin. Exp. Immumol. 8:, 293-296
64 Demidem, A., Taylor, J.R., Grammer, S.F. and Streilein, J.W. (1991) J. Intest. Dermatol. 97, 454-460

65 Prens, E.P., Benne, K., Van Joost, T. and Benner, R. (1991) J. In'est. Dermatol. 96, 880-887

66 Morganrorh, G.S., Chan, L..S., Weinstein, G.D.,

Voorhees, J.J. and Cooper, K.D. (1991) J. Invest. Dermatol. 96, 333-j40

67 Furue, M. and Katz, S.I. (1988) J. Immunol. 140, $4139-4143$

68 Dupuy, P., Bagot, M., Michel, L., Descourt, B. and Dubertret, L. (1991) J. Invest. Dermatol. 96, 408-413 69 Brain, S.D., Camp, R.D.R., Cunningham, F.M. et al. (1984) Br. J. Pharmacol. 83, 313-317

70 Pigatto, P.D., Pigatto, L.B., Bigardi, A., Altomare, G. and Finzi, A.F. (1990) J. Invest. Dermatol. 94, 372-376

71 Groves, R.W., Allen, M.h., Barker, J.N.W.N., Haskard, D.O. and Macdonald, D.M. (1991) Br. J. Dermatol. 124, $117-123$

72 Chin, Y., Falanga, V., Taylor, J.R., Cai, J.P. and Bax, J. (1990) J. Invest. Dermatol. $94,413-417$

73 Petzelbauer, P., Stingl, G., Wolff, K., and Volc-Platzer, B. (1991) J. Invest. Dermatol. 96, 362-369

74 Triggiani, M., Cirillo, R., Lichtenstein, L.M and Marone, G. (1989) Internat. Arch. Allergy Appl. Immunol. 88, 253-255

75 Hultsch, T., Rodriguez, J.L., Kaliner, M.A. and Hohman, R.J. (1990) J. Immunol. 144, 2659-2664

Due to the separation of the Czech and Slovak republic the Czech Academy of Sciences is suffering from lack of funding; the Institute of Microbiology will close unless it can find some extra income.

The Academy is able to breed for commercial purposes certain strains of inbred mice, rats, pigs and rabbits and can also provide laboratory facilities for experiments on such animals by visiting scientists.

Any income generated from these facilities would save the Gnotobiological Laboratory and help to maintain immunological research in the Academy.

If you feel able to use these facilities or are in a position to help fund the immunological research in the Czech Academy of Sciences, please contact:

\author{
Dr Helena Tlaskalová \\ Dept of Immunology and Gnotobiology \\ Institute of Microbiology \\ Czechoslovak Academy of Sciences \\ Videnska 1083 \\ 14220 Prague 4 \\ KRC
}

